\title{
Product qualities and sensory evaluation of high protein snack bar incorporated with pea protein isolate
}

\author{
${ }^{1}$ Gunyaphan, S., ${ }^{1}$ On-nom, N., ${ }^{1}$ Suttisansanee, U., ${ }^{2}$ Nana, A., ${ }^{1}$ Chamchan, R., \\ ${ }^{1}$ Khemthong, C. and ${ }^{1, *}$ Chupeerach, C. \\ ${ }^{1}$ Institute of Nutrition, Mahidol University, Salaya, Thailand \\ ${ }^{2}$ College of Sports Science and Technology, Mahidol University, Salaya, Thailand
}

Article history:

Received: 22 May 2020

Received in revised form: 25 July 2020

Accepted: 12 November 2020 Available Online: 6

December 2020

\section{Keywords:}

Snack bar,

Pea protein isolate (ppi),

Product qualities,

Nutritive values,

Sensory evaluation

DOI:

https://doi.org/10.26656/fr.2017.4(S4).008

\begin{abstract}
Snack bars are convenient and nutritious food composed of several ingredients. It also can be supplemented by some health-promoting substances such as pea protein isolate (PPI). The aim of this study was to formulate a high-protein snack bar using pea protein isolate using INMUCAL-Nutrients V.4.0. Moreover, the product qualities of PPI snack bars in term of physical and sensory qualities and nutritive values were also determined. Protein content of the PPI snack bars (20-25 g per $100 \mathrm{~g}$ sample) was criteria for the formulation. As the result the physical qualities of PPI snack bars showed that water activity was below 0.65 , therefore snack bars should be stable against microbial growth. No significant difference was found in color values between the PPI snack bar and the control formula, but PPI snack bars had higher hardness than the control formula. The energy, carbohydrate, protein, fat and dietary fiber of PPI snack bar was $439.40 \mathrm{kcal}, 46.88 \mathrm{~g}$, $22.20 \mathrm{~g} 18.12 \mathrm{~g}$ and $7.17 \mathrm{~g}$ per $100 \mathrm{~g}$, respectively. Moreover, it had balanced energy distribution of carbohydrate: protein: fat at 54:25:21. The results from the sensory evaluation indicated that the liking score of appearance, color, odor, taste texture and overall liking of PPI snack bars were higher than 7 (like moderately). Therefore, PPI appears to be an alternative ingredient used to improve the nutritional quality of the high protein diet bar.
\end{abstract}

\section{Introduction}

Nutrition, convenience, price and sensory attributes are important characteristics in determining the acceptability of a food product (Boustani and Mitchell, 1990; Bower and Whitten, 2000). According to Roberfroid (1999), one of the major challenges is to provide busy consumers with healthy ready-to-eat foods. Snack bars are convenient and practical for nutrient intake, representing an alternative food supplement based on carbohydrates, proteins and fibers and, in addition, can be supplemented by some health-promoting substances, such as antioxidants, which is a current trend in the food sector. Although the process for manufacturing snack bars is relatively easy, incorporating high amounts of functional components can be difficult due to the individual characteristics of the components and their interactions with corn syrup or other ingredients. In addition, these functional components can be detrimental to sensory characteristics, such as texture and taste, and physical properties, such as water activity.
Pea protein isolate (PPI) is a protein isolate obtained from pea (Pisum sativum) containing $85 \%$ of proteins and particularly rich in essential branch-chain amino acid (BCAA; leucine, isoleucine and valine) known to play an important role in muscle protein synthesis (Stark et al., 2012). Balage and Dardevet (2010) reported that an increased plasma concentration in leucine favors muscle protein synthesis and that its action on muscle mass is potentiated by the presence of other amino acids such as those contained in NUTRALYS ${ }^{\circledR}$ pea protein. Moreover, Babault et al. (2015) reported that when $25 \mathrm{~g}$ protein was consumed twice a day during 12-week training period. It can provide health benefits. Therefore, pea protein could contribute to muscle protein synthesis when taken immediately after resistance exercises (Chesley et al., 1992; Biolo et al., 1995; Phillips et al., 1997).

The addition of PPI to the food product, such as snack bars, may be an option for healthy people or people who would like to increase of muscle thickness and strength. Therefore, this study aimed to develop a 
high-protein snack bar that has protein content over $20 \%$ Thai RDI by using PPI, in order to obtain an easily consumed food with high protein as well as greater acceptability.

\section{Materials and methods}

\subsection{Raw materials}

The ingredients used for producing manufacture the snack bar were pea protein isolate (Argi-Mark Co., USA), oat mill (PepsiCo (THAI) Co, Thailand), almond (Rainbowfood Co, Thailand), peanut and cashew nut (Raithip Co, Thailand), cornflake (Kellogg Co., Ltd, Thailand), crispy rice (Phuweang group, Khon Kaen, Thailand), glucose syrup (Sangphet Co, Thailand), honey (Peeraphan bee farm, Thailand), evaporated milk (F\&N dairy Co., Ltd, Thailand), coconut oil (Lamsoong Co., Ltd, Thailand) peanut butter (DKSH Co., Ltd, Thailand), butter (The Thai dairy Industry Co., Ltd, Thailand) and chocolate coating (Sino-Pacific trading Co., Ltd, Thailand). Raisin was purchased from the local market in Bangkok Thailand.

\subsection{Snack bar preparation}

The formulas of snack bars were modified from the commercial snack bar recipes as shown in Table 1 . The preparation of snack bars was done by mixing all dry ingredients. The wet and semi-solid ingredients such as honey, coconut oil were mixed together in another beaker and heated till melted in order to prepare a binder for dried ingredients. Then, the binder was mixed together and thoroughly incorporated into the dry ingredients. A total of $33 \mathrm{~g}$ of mixture was then put into small baking molds $\left(3.5 \times 10 \times 2 \mathrm{~cm}^{3}\right)$, compressed for 1 min with a $1 \mathrm{~kg}$ weight, cooked at $120^{\circ} \mathrm{C}$ for 10 mins in a fan oven and then cover and left to cool in the refrigerator for 20 mins. After unmolding, the bars were coated with diet milk chocolate, totaling $45 \pm 2 \mathrm{~g}$ of final mass. Finally, the bars were packed in aluminum foil bags and refrigerated for further study.

Table 1. Ingredients used in the snack bar formulations.

\begin{tabular}{lccc}
\hline Ingredient (\%) & Formula A & Formula B & Formula C \\
\hline Almond & 29.31 & 4 & 8.07 \\
Peanut & - & 4 & 8.07 \\
Cashew nut & - & 4 & 8.07 \\
Oat mill & 32.97 & 10.3 & 18.18 \\
Raisin & - & 12 & 7.27 \\
Glucose syrup & - & 12 & 23.26 \\
Peanut butter & 17.58 & - & - \\
Cornflake & - & 20 & 6.06 \\
Honey & 14.65 & 17.6 & 12.21 \\
Butter & - & - & - \\
Coconut oil & 5.49 & 4.4 & 4.26 \\
Evaporated milk & - & 11.7 & 4.55 \\
\hline
\end{tabular}

\subsection{Formulation of PPI snack bar}

The formulation aimed for the product that had protein content at 20-25 g per $100 \mathrm{~g}$ snack which could be claimed as high protein product as according to Thai FDA regulation on nutrition labeling report (Food and Drug Administration, 1998). PPI was selected as a source of protein due to PPI had sufficient amounts of protein to provide health benefits described by previous studies (Babault et al., 2015). The formulation was performed using INMUCAL-Nutrients V.4.0. Then, the preparation of PPI snack bars was the same as the above process.

\subsection{Sensory evaluation}

Sensory evaluation was conducted with 30 semitrained panelists comprised of faculty members, staffs and graduate students of the Institute of Nutrition, Mahidol University (INMU), Thailand. Criteria for recruitment are 18-40 years of age, regular snack bar consumers and no history of allergy to protein, peanut, cashew nut, almond, oat and PPI. The panelists were educated on testing terminologies and requested to evaluate the various snack bar samples for color, odor, taste, texture, and overall liking using a 9-point (Meilgaard et al., 1999). The test was performed in an individual testing booth under the daylight-fluorescent lights of the sensory science laboratory at INMU. $15 \mathrm{~g}$ of samples were packed in aluminum foil bags and coded using random three-digit numbers. Panelists were provided with a glass of water and, instructed to rinse and swallow water between samples. The protocol was approved by the Mahidol University Ethical Board (MUCIRB) (No. MU-CIRB 2019/208.1308).

\subsection{Quality analysis}

\subsubsection{Physical quality}

Water activity: Water activity was determined using a portable water activity meter (model ms 1 , Novasina, Switzerland) at $25 \pm 1{ }^{\circ} \mathrm{C}$.

Color measurement: the color values were determined using Hunter Lab Digital Colorimeter (COLORFLEX 4510 model, USA). The CIE color values were recorded as $\mathrm{L}^{*}$ (lightness), $\mathrm{a}^{*}$ (redness) and $b^{*}$ (yellowness).

Texture analysis: measurements were performed at ambient temperature (approximately $25 \pm 2^{\circ} \mathrm{C}$ ) using a texture analyzer (TA.XT plus, Stable Micro Systems Ltd, YL, UK) equipped with a 3-Point Bending Rig (HDP/3PB) (Jambrec et al., 2013). Testing condition is probe distance of $5 \mathrm{~mm}$, test speed of $0.5 \mathrm{~mm} / \mathrm{sec}$ with a trigger force of $5 \mathrm{~g}$. Hardness (peak force) was the 
maximum resistance of each cookie against a roundededge blade and occurred when the sample began to break (Levent and Bilgiçli, 2013). The results represented an average of twelve measurements.

\subsubsection{Chemical quality}

Proximate analysis: the moisture content, ash, protein, fat, carbohydrate, dietary fiber and sugar were determined using the standard method of AOAC (AOAC, 2016). The calorie content was calculated based on the contents of protein, fat and carbohydrate.

\subsection{Statistical analysis}

The experiment design was a completely randomized design (CRD) for physical properties and nutritional values and Randomized Complete Block Design (RCBD) for the sensory analysis. All measurement except sensory evaluation was performed in triplicates. Experimental data were analyzed using computer software (IBM SPSS Statistics 19.0 IBM, Chicago, Illinois, USA). Independent sample t-test or one-way Analysis of Variance (ANOVA) and Duncan's multiple range tests was performed to compare mean value. Average values are considered significantly different when $\mathrm{p}<0.05$.

\section{Results and discussion}

\subsection{Selection of the control formula for PPI snack bar preparation}

There were three different snack bar formulas which had been used to prepare snack bars. The sensory evaluations of three different snack bars are shown in Table 2 . The sensory evaluation indicated that formula B obtained the significantly lower sensory score than formula $\mathrm{A}$ and $\mathrm{C}$. This might be due to the amount of nut used in the snack bars. It seemed that amount of nut in formula B was less than formula A and C. In addition, there was no statistically significant difference on the sensory score of appearance, flavor, taste, texture and overall liking between formula $\mathrm{A}$ and formula C. However, the cost estimation found that formula $\mathrm{C}$ was

Table 2. Sensory evaluation of three different snack bar formulas

\begin{tabular}{cccc}
\hline & Formula A & Formula B & Formula C \\
\hline Appearance & $6.90 \pm 1.30^{\mathrm{a}}$ & $5.97 \pm 1.75^{\mathrm{b}}$ & $6.87 \pm 1.01^{\mathrm{a}}$ \\
Color & $7.07 \pm 1.05^{\mathrm{a}}$ & $6.27 \pm 1.48^{\mathrm{b}}$ & $7.00 \pm 0.98^{\mathrm{a}}$ \\
Odor & $7.07 \pm 1.28^{\mathrm{a}}$ & $6.00 \pm 1.72^{\mathrm{b}}$ & $6.67 \pm 1.15^{\mathrm{ab}}$ \\
Taste & $6.73 \pm 1.28^{\mathrm{a}}$ & $5.73 \pm 2.11^{\mathrm{b}}$ & $6.86 \pm 0.97^{\mathrm{a}}$ \\
Texture & $5.80 \pm 1.69^{\mathrm{ab}}$ & $5.50 \pm 1.98^{\mathrm{b}}$ & $6.60 \pm 1.10^{\mathrm{a}}$ \\
Overall liking & $6.47 \pm 1.30^{\mathrm{a}}$ & $5.60 \pm 1.87^{\mathrm{b}}$ & $7.00 \pm 0.74^{\mathrm{a}}$ \\
\hline
\end{tabular}

Data were represented as mean \pm SD. Different letters in same row indicate significant difference at $\mathrm{p}<0.05$ by Duncan multiple range test. cheaper than $\mathrm{A}$, so the formula $\mathrm{C}$ was selected to be the control formula in order to formulate PPI snack bars.

\subsection{Formulation of PPI snack bars}

The formulation in this study was using PPI to increase the protein content in the snack bar. The sufficient amount of protein content that provides the health benefits described by previous studies (Chesley et al., 1992). INMUCAL-Nutrients V.4.0 was used to calculate the amount of ingredient used in order to obtain 20-25 g of protein per $100 \mathrm{~g}$ snack bar. Table 3 shows the percentages of different ingredients that were used in the PPI snack bar. Nut and oat which are the source of carbohydrate were replaced with PPI as a source of protein. Moreover, crispy rice was added to improve the texture of the product. According to the calculation using INMUCAL-Nutrients V.4.0, the formulation in Table 3 provides energy, carbohydrate, protein, fat and dietary fiber of $401.44 \mathrm{kcal}, 45.94 \mathrm{~g}, 31.61 \mathrm{~g}, 10.14 \mathrm{~g}$ and $1.78 \mathrm{~g}$ per $100 \mathrm{~g}$ sample, respectively. It seemed that the protein content of the sample which was calculated by INMUCAL-Nutrients V.4.0 achieved the aimed level (protein 20-25 g per $100 \mathrm{~g}$ snack bar). Therefore, this PPI snack bar formulation was used to determine product qualities by comparing with the control formula.

Table 3. Percentages of ingredients used in the PPI snack bar formula by INMUCAL-Nutrients

\begin{tabular}{lc}
\hline Ingredients (\%) & PPI snack bar \\
\hline PPI & 39.97 \\
Raisin & 7.27 \\
Honey & 12.21 \\
Evaporate milk & 4.55 \\
Glucose syrup & 23.26 \\
Coconut oil & 4.26 \\
Crispy rice & 8.48 \\
\hline
\end{tabular}

\subsection{Product qualities}

\subsubsection{Physical qualities}

Table 4 shows the physical qualities of PPI snack bars and the control snack bars. Water activity has a determining effect on the rate of many chemical reactions in foods and on the rate of microbial growth. Moulds and yeasts start to grow at a water activity between 0.7 and 0.8 (Aramouni and Mahmoud, 2011; Bchir et al., 2012). Bacterial growth takes place when water activity reaches 0.8 (Bchir et al., 2012). The results showed that the water activity of both samples was not significantly different $(\mathrm{p}<0.05)$. Moreover, all water activity level is below 0.7 , therefore snack bars should be stable against microbial growth and could persist for about six months (Aramouni and Mahmoud, 2011). Color is one important parameter of the product (Aramouni and Mahmoud, 2011). For the color measurement, PPI snack bars had lower L* values which 
indicated that they were darker in color. The $a^{*}$ and $b^{*}$ values for color represent the red-green and blue-yellow axis, respective. PPI snack bars had a highly red color but weak yellow color than the control formula. The hardness of both snack bars was determined using texture analyzer as shown in Table 4 . The results show that PPI snack bars had a harder texture compared to the control formula. This could be due to the high amount of protein in the product. The result was in agreement with Sunyoto et al. (2019) who reported that an increase in mung bean flour content caused an increased the hardness of high protein snack bar.

Table 4. Physical qualities of PPI snack bar compared with the control formula

\begin{tabular}{lcc}
\hline Physical qualities & Control snack bar & PPI snack bar \\
\hline Water activity & $0.58 \pm 0.00^{\mathrm{a}}$ & $0.56 \pm 0.00^{\mathrm{a}}$ \\
Color & & \\
$L^{*}$ & $34.56 \pm 7.80^{\mathrm{a}}$ & $24.48 \pm 0.33^{\mathrm{a}}$ \\
$a^{*}$ & $4.44 \pm 1.20^{\mathrm{a}}$ & $5.75 \pm 0.04^{\mathrm{a}}$ \\
$b^{*}$ & $13.96 \pm 6.48^{\mathrm{a}}$ & $4.21 \pm 0.14^{\mathrm{b}}$ \\
Hardness (N) & $24.70 \pm 3.19^{\mathrm{b}}$ & $116.98 \pm 13.25^{\mathrm{a}}$ \\
\hline
\end{tabular}

Data were represented as mean \pm SD. Different letters in same row indicate significant difference at $\mathrm{p}<0.05$ by Duncan multiple range test.

\subsubsection{Nutritive values}

Results of nutritive values of PPI snack bars and the control snack bars are shown in Table 5. It was found that PPI snack bars contain higher amount of protein and dietary fiber than the control formula. However, energy, fat and carbohydrate of the PPI snack bars were lower than the control formula. This could be due to the replacement of nut and oat with PPI. According to Thai FDA regulation on nutrition labeling, it stated that product which contains $20 \%$ Thai RDI, it could be claimed as high protein. The results presented that protein content of PPI snack bar was $22.20 \%$ Thai RDI so this product could be claimed as high protein. The energy distribution of carbohydrate, protein and fat of the PPI snack bars was 54:25:21 which are in range of the Thai Dietary Reference Intakes (Food and Drug Administration, 1998). Moreover, the energy of PPI Table 5. Nutritive values of PPI snack bar compared with the control snack bar formulas

\begin{tabular}{lcc}
\hline Nutritive values & Control snack bar & PPI snack bar \\
\hline Energy $(\mathrm{kcal} / 100 \mathrm{~g})$ & $475.30 \pm 3.72^{\mathrm{a}}$ & $439.40 \pm 5.43^{\mathrm{b}}$ \\
Moisture $(\%)$ & $9.51 \pm 0.76^{\mathrm{a}}$ & $10.60 \pm 0.40^{\mathrm{a}}$ \\
Protein $(\mathrm{g} / 100 \mathrm{~g})$ & $7.85 \pm 0.31^{\mathrm{b}}$ & $22.20 \pm 1.54^{\mathrm{a}}$ \\
Total fat $(\mathrm{g} / 100 \mathrm{~g})$ & $23.74 \pm 0.14^{\mathrm{a}}$ & $18.12 \pm 0.50^{\mathrm{b}}$ \\
Total carbohydrate $(\mathrm{g} / 100 \mathrm{~g})$ & $57.56 \pm 0.77^{\mathrm{a}}$ & $46.88 \pm 0.19^{\mathrm{b}}$ \\
Ash $(\mathrm{g} / 100 \mathrm{~g})$ & $1.34 \pm 0.35^{\mathrm{a}}$ & $2.20 \pm 0.06^{\mathrm{a}}$ \\
Dietary fiber $(\mathrm{g} / 100 \mathrm{~g})$ & $5.88 \pm 0.05^{\mathrm{b}}$ & $7.17 \pm 0.22^{\mathrm{a}}$ \\
\hline
\end{tabular}

Data were represented as mean \pm SD. Different letters in same row indicate significant difference at $\mathrm{p}<0.05$ by Duncan multiple range test. snack bar was in the range to that found by Santos et al. (2011) (300-413 kcal/100 g). Snack bars with a high energy is very sought by top sportsmen levels to improve their performance. Therefore, PPI snack bars could be introduced in diet of sportsmen.

\subsubsection{Sensory evaluation}

In case of sensory evaluation, Table 6 shows that no significant difference was found on sensory score of appearance, color between PPI snack bar and the control snack bar. The liking score of appearance and color of both formulas are in agreement with the color values that shows no significant difference between these two formulas. However, the hardness of the PPI snack bars was higher than the control formula but the liking score on texture did not show a significant difference. This means that the range of hardness of snack bar is between 24.52-117.68 N were accepted. Moreover, the PPI snack bars obtained significantly higher score on odor and taste. This might be due to protein content causes Mailard's reaction on baking process. Mailard's reaction produces melanoidin compounds which are the main compounds in shaping the tastes (Manley, 2001). In addition, volatile compound is the aroma caused by the roasting process. The aroma arises from the interaction between odorous substances with olfactory epithelial cells in the smell senses (Nurjanah, 2014). The overall liking score of PPI snack bars was 7.30 (like moderately) which was not significant difference with the control formula.

Table 6. Sensory evaluation of PPI snack bar compared with the control snack bar formulas

\begin{tabular}{lcc}
\hline Sensory attributes & Control snack bar & PPI snack bar \\
\hline Appearance & $6.87 \pm 1.01^{\mathrm{a}}$ & $7.37 \pm 0.89^{\mathrm{a}}$ \\
Color & $7.00 \pm 0.98^{\mathrm{a}}$ & $7.33_{ \pm} 0.88^{\mathrm{a}}$ \\
Odor & $6.67 \pm 1.15^{\mathrm{b}}$ & $7.63_{ \pm} 0.67^{\mathrm{a}}$ \\
Taste & $6.86 \pm 0.97^{\mathrm{b}}$ & $7.53_{ \pm} 1.48^{\mathrm{a}}$ \\
Texture & $6.60 \pm 1.10^{\mathrm{a}}$ & $7.10_{ \pm} 1.03^{\mathrm{a}}$ \\
Overall liking & $7.00 \pm 0.74^{\mathrm{a}}$ & $7.30 \pm 1.18^{\mathrm{a}}$ \\
\hline
\end{tabular}

Data were represented as mean \pm SD. Different letters in same row indicate significant difference at $\mathrm{p}<0.05$ by Duncan multiple range test.

\section{Conclusion}

Pea protein isolate could be used successfully as a food ingredient to develop new formulations of snack bars. Indeed, based on the obtained results it could be concluded that the snack bar with PPI provided an increase of protein and fiber as well as a reduced value of carbohydrate and fat. In addition, the PPI snack bars were well accepted in the sensory analysis. Therefore, this PPI snack bars could be recommended to both practitioners of physical exercise (healthy population) as well as sportsmen (special population). 


\section{Conflict of interest}

The authors have no potential conflict of interest.

\section{Acknowledgements}

This work was supported by Institute nutrition Mahidol University.

\section{References}

AOAC. (2016). Official Methods of Analysis of AOAC International, 20th ed. Gaithersburg, USA: AOAC.

Aramouni, F. and Mahmoud, A. (2011). Physicochemical and sensory characteristics of nobake wheat-soy snack bars. Journal of Science of Food and Agriculture, 91(1), 44-51. https:// doi.org/10.1002/jsfa.4134

Babault, N., Païzis, C., Deley, L.G., Saniez M.H., Lefranc-Millot, C. and Allaert, F.A. (2015). Pea proteins oral supplementation promotes muscle thickness gains during resistance training: a doubleblind, randomized, placebo-controlled clinical trial vs. whey protein. Journal of the International Society of Sports Nutrition, 12, 3. https:// doi.org/10.1186/s12970-014-0064-5

Balage, M. and Dardevet, D. (2010). Long-term effects of leucine supplementation on body composition. Current Opinion in Clinical Nutrition and Metabolic Care, 13(3), 265-270. https://doi.org/10.1097/ MCO.0b013e328336f6b8

Bchir, B., Besbes, S., Karoui, R., Attia, H., Paquot, M. and Blecker, C. (2012). Effect of air-drying conditions on physico-chemical properties of osmotically pre-treated pomegranate seeds. Food Bioprocess Technology, 5, 1840-1852. https:// doi.org/10.1007/s11947-010-0469-3

Biolo, G., Maggi S.P., Williams, B.D., Tipton, K.D. and Wolfe R.R. (1995). Increased rates of muscle protein turnover and amino acid transport after resistance exercise in humans. American Journal of Physiology, 268(3), E514-E520. https:// doi.org/10.1152/ajpendo.1995.268.3.E514

Boustani, P. and Mitchell, V.W. (1990). Cereal bars: a perceptual, chemical and sensory analysis. British Food Journal, 92(5), 17-22. https:// doi.org/10.1108/00070709010003652

Bower, J.A. and Whitten, R. (2000). Sensory characteristics and consumer linking for cereal bar snack foods. Journal of Sensory Studies, 15(3), 327345. https://doi.org/10.1111/j.1745459X.2000.tb00274.x

Chesley, A., MacDougall, J.D., Tarnopolsky, M.A., Atkinson, S.A. and Smith, K. (1992). Changes in human muscle protein synthesis after resistance exercise. Journal of Applied Physiology, 73(4), 1383 -1388. https://doi.org/10.1152/jappl.1992.73.4.1383

Food and Drug Administration, Ministry of Public Health Thailand. (1998). Notification of Ministry of Public Health (No. 182) B.E. 2541 (1998) Re: Nutrition Labeling. Retrieved from website: http:// food.fda.moph.go.th/law/data/announ_moph/ V.English/No.182-41\%20Nutrition\%20Labelling.pdf Jambrec, D., Pestorić, M., Sakač, M., Nedeljković, N., Hadnađev, M., Filipčev, B. and Šimurina, O. (2013). Sensory and instrumental properties of novel glutenfree products. Journal Process of Agriculture, 17(2), 86-88.

Levent, H.J. and Bilgiçli N. (2013). Quality evaluation of wheat germ cake prepared with different emulsifiers. Journal of Food Quality, 36(5), 334-341. https:// doi.org/10.1111/jfq. 12042

Manley, D.J.R. (2001). Biscuit, Cracker, and cookie recipes for the food industry. Abington, England: Woodhead Publishing Ltd. https:// doi.org/10.1533/9781855736269

Meilgaard, M., Civille, G.V. and Carr B.T. (1999). Sensory Evaluation Techniques. 3rd ed. Boca Raton: CRC Press. https://doi.org/10.1201/9781439832271

Nurjanah, M. (2014). Characteristics of snack bar made of rasi-mung bean flour, and rasi-kidney bean flour. Jatinangor: Padjadjaran University, Thesis.

Phillips, S.M., Tipton, K.D., Aarsland, A., Wolf, S.E. and Wolfe, R.R. (1997). Mixed muscle protein synthesis and breakdown after resistance exercise in humans. American Journal of Physiology, 273, E99 - $\quad$ E107. ajpendo.1997.273.1.E99

Roberfroid, M.B. (1999). Concepts in functional foods: the case of inulin and oligofructose. Journal of Nutrition, 129(7), 1398S-1401S. https:// doi.org/10.1093/jn/129.7.1398S

Santos, C.T., Bonomo, R.F., Fontan, R.C., Bonomo, P., Veloso, C.M. and Fontan, G.C. (2011). Characterization and sensorial evaluation of cereal bars with jackfruit. Acta Scientiarum Technology, 33 (1), 81-85. https://doi.org/10.4025/ actascitechnol.v33i1.6425

Stark, M., Lukaszuk J., Prawitz A. and Salacinski, A. (2012). Protein timing and its effects on muscular hypertrophy and strength in individuals engaged in weight-training. Journal of the International Society of Sport Nutrition, 9, 54. https:// doi.org/10.1186/1550-2783-9-54

Sunyoto, M., Andoyo, R. and Masitoh, E. (2019). Characteristics of high protein snack bar made of modified sweet potato flour. IOP Conference Series: Earth and Environmental Science, 347, 012064. https://doi.org/10.1088/1755-1315/347/1/012064 